\title{
Organisational Response to the 2007 Ruapehu Crater Lake Dam-Break Lahar in New Zealand: Use of Communication in Creating an Effective Response
}

\author{
Julia S. Becker (10, Graham S. Leonard, Sally H. Potter, \\ Maureen A. Coomer, Douglas Paton, Kim C. Wright \\ and David M. Johnston
}

\begin{abstract}
When Mt. Ruapehu erupted in 1995-1996 in New Zealand, a tephra barrier was created alongside Crater Lake on the top of Mt. Ruapehu. This barrier acted as a dam, with Crater Lake rising behind it over time. In 2007 the lake breached the dam and a lahar occurred down the Whangaehu Valley and across the volcano's broad alluvial ring-plain. Given the lahar history from Ruapehu, the risk from the 2007 event was identified beforehand and steps taken to reduce the risks to life and infrastructure. An early warning system was set up to notify when the dam had broken and the lahar had occurred. In combination with the warning system, physical works to mitigate the risk were put in place. A planning group was also formed and emergency management plans were put in place to respond to the risk. To assess the effectiveness of planning for and responding to the lahar, semi-structured interviews were undertaken with personnel from key organisations both before and after the lahar event. This chapter discusses the findings from the interviews in the context of communication, and highlights how good communication contributed to an effective emergency management response. As the potential for a lahar was identifiable, approximately 10 years of lead-up time was available to
\end{abstract}

J.S. Becker $(\bowtie) \cdot$ G.S. Leonard · S.H. Potter M.A. Coomer - D.M. Johnston Joint Centre for Disaster Research, GNS Science, P.O. Box 30368, Lower Hutt, New Zealand e-mail: j.becker@gns.cri.nz

G.S. Leonard

e-mail: g.leonard@gns.cri.nz

S.H. Potter

e-mail: s.potter@gns.cri.nz

M.A. Coomer

e-mail: m.coomer@gns.cri.nz

D.M. Johnston

e-mail: david.johnston@gns.cri.nz
D.M. Johnston

Joint Centre for Disaster Research, School of Psychology, Massey University, P.O. Box 756, Wellington 6140, New Zealand

D. Paton

School of Psychological and Clinical Sciences, Charles Darwin University, Darwin, NT 0909, Australia e-mail: douglas.paton@cdu.edu.au

K.C. Wright

Ministry of Civil Defence \& Emergency Management, Wellington, New Zealand e-mail: Kim.Wright@dpmc.govt.nz 
install warning system hardware, implement physical mitigation measures, create emergency management plans, and practice exercises for the lahar. The planning and exercising developed effective internal communications, engendered relationships, and moved individuals towards a shared mental model of how a respond to the event. Consequently, the response played out largely as planned with only minor communication issues occurring on the day of the lahar. The minor communication issues were due to strong personal connections leading to at least one incidence where the plan was bypassed. Communication levels during the lahar event itself were also different from that experienced in exercises, and in some instances communication was seen to increase almost three-fold. This increase in level of communication, led to some difficulty in getting through to the main Incident Control Point. A final thought regarding public communication prior to the event was that more effort could have been given to developing and integrating public information about the lahar, to allow for ease of understanding about the event and integration of information across agencies.

\section{Keywords}

Volcano - Lahar - Communication - Emergency management planning • Mt. Ruapehu • New Zealand

\section{Introduction}

\subsection{Background}

In 1995 and 1996 Mt. Ruapehu in New Zealand underwent a series of eruptions that initiated approximately 30 eruption-induced lahars, and several ash falls over parts of New Zealand's North Island (Galley et al. 2004; Cronin et al. 1997; Johnston et al. 1999). A tephra layer was also deposited at the head of the Whangaehu Valley on the Ruapehu Crater Lake outflow channel, creating a natural dam to the lake (Manville et al. 2007). Over time it was anticipated that the water in the Crater Lake would rise behind the dam to a volume of 7-9 million cubic metres, and eventually breach it, resulting in a dam-break lahar (Keys and Green 2008). This lahar would travel down the Whangaehu Valley, and despite much of the area being quite remote, people and infrastructure were potentially in danger (Fig. 1). In addition to many lahars caused by other factors (such as eruptions and rain mobilisation; Keys and Green 2008), previous dam-break lahars are known to have occurred from Ruapehu, including a devastating lahar in 1953. In that instance, the dam-break lahar travelled down the valley and seriously damaged a rail bridge at the location of Tangiwai (Board of Inquiry 1954). Soon after, a passenger train hurtled into the lahar-flooded Whangaehu River and 151 people died. Given the consequences of the 1953 event, and the anticipation that a new dam-break lahar could occur, it was considered imperative that something be done to reduce the risk from a potential future event. Options included removing the tephra dam through to planning an emergency management response to a break-out lahar. The dam-break lahar eventually occurred on 18 March 2007. This chapter describes the mitigation and planning actions that were taken to reduce the risk, and based on a 


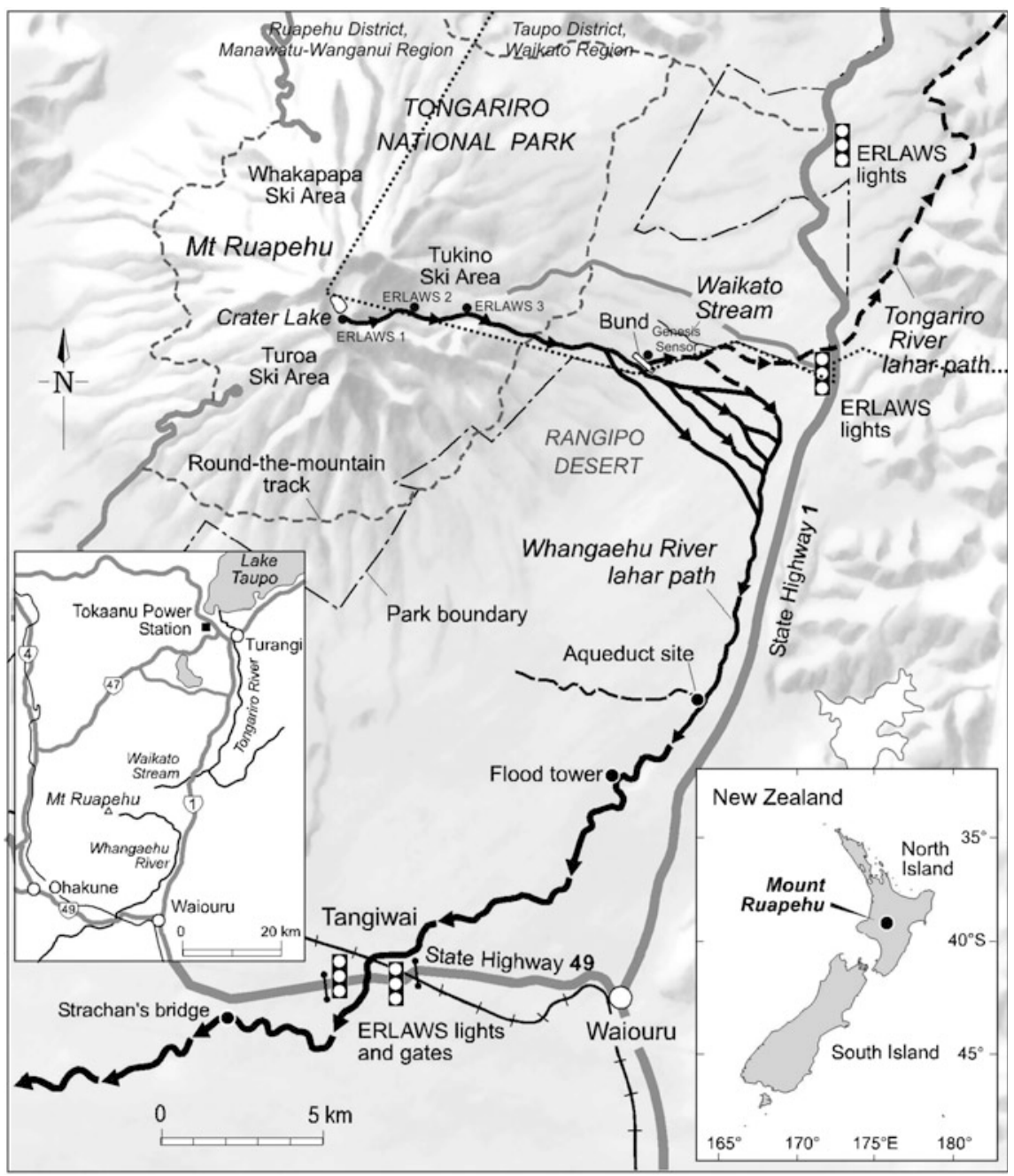

Fig. 1 Map of Mt. Ruapehu Crater Lake, showing potential lahar path, and locations of significance (adapted from Keys and Green 2008)

series of interviews with those involved in the planning process, outlines the role of communication in creating an effective response.

\subsection{What to Do About an Anticipated Lahar?}

A number of studies were conducted to assess the hazard and risk of a dam-break lahar at Ruapehu (e.g., Hancox et al. 1997, 1998; Taig 2002) and to identify options for reducing the risk (DOC 1999). While some strongly advocated for intervention at the tephra dam, e.g., digging a tunnel through the barrier to remove the potential for catastrophic collapse (Hancox et al. 1997), it was decided that no engineering intervention should take place (Keys 2007b). Instead, a mixture of warning systems, mitigation works and emergency planning was instigated to deal with the dam-break lahar issue (Keys and Green 2002, 2008; Norton 2002; Massey et al. 2009).

To mitigate the risk of a lahar, a 'bund' (levee) was built in early 2002 at the spill-over point of the Whangaehu River into the Waikato Stream (Galley et al. 2004). The objective of this was to stop a lahar from getting into the catchment of the Tongariro River and thus protecting infrastructure 
(i.e. Tongariro Power Station) and people downstream. Other mitigation works included making changes to infrastructure at risk from the lahar, such as strengthening and raising the road bridge at Tangiwai by two metres (Wakelin 2006).

At about the same time as the bund was built a warning system called the Eastern Ruapehu Lahar Warning System (ERLAWS) was set up. ERLAWS (a system of sensors and preventative mechanisms) was designed to sense vibrations when the lahar had been triggered and send electronic warnings out to people (e.g., via pager, computers, electronic road signs), so that emergency responders could initiate a response (Keys 2009; Leonard et al. 2008; Wakelin 2006; Massey et al. 2009). The system was expected to give a maximum of one hour of warning of the impending lahar at State Highway One (SH1) on the Desert Road, and two hours warning at the Tangiwai Bridge (Wakelin 2006).

While the ERLAWS in particular was a good way of detecting when a Crater Lake lahar had been triggered, the system was also subject to being set off accidentally and creating a 'false alarm'. This could particularly occur when rain storm events caused heightened stream flow.

An Eruption Detection warning System (EDS) was also present on Ruapehu and provided an additional avenue for warning of lahars. The EDS is triggered by earthquakes when an eruption of a certain size occurs, allowing warning for lahars that are potentially generated by volcanic eruptions (Leonard et al. 2008). Such lahars usually occur from hot volcanic material falling on snow and melting the snow to generate a lahar which could then impact on the local ski fields. However, an eruption could also potentially generate a Crater Lake break-out lahar if a dam has blocked the lake, and thus the EDS provided another warning option for the dam-break lahar situation.

Another element of managing a Ruapehu Crater Lake dam-break lahar was that of emergency planning. It was decided that response plans should be prepared to deal with a dam-break lahar if, and when, it occurred (Keys 2009). The region affected by a potential lahar was divided into two parts: a Northern part which would only be affected if a lahar were to overtop the bund and get into the Waikato Stream and Tongariro River; and a Southern part which was the main area that would be affected if a lahar moved from Ruapehu Crater Lake via the Whangaehu River to the sea. A Northern Ruapehu Lahar Planning Group and a Southern Ruapehu Lahar Planning Group were formed to develop plans on an effective response for before, during and after a dam-break lahar event. Both groups were convened by 2003 (Galley et al. 2004). The following section describes the nature of the planning undertaken by these groups in the anticipation of responding effectively to a lahar.

\subsection{Planning a Response to a Ruapehu Crater Lake Lahar}

Taupo District Council (TDC) took on primary responsibility for developing the Northern Emergency Management Plan, while the Ruapehu District Council (RDC) took on primary responsibility for the Southern Emergency Management Plan. Development and refinement of the plans took place in collaboration with many other organisations with responsibilities (Table 1), with the final sign-off occurring in 2004 for the Northern Plan (Northern Lahar Planning Group 2004) and in 2005 for the Southern Plan (Southern Lahar Planning Group 2005).

A central Incident Control Point (ICP) in the town of Ohakune was identified in the plan. The ICP was where the majority of responders would meet to coordinate response to the lahar. There were also a number of agencies that would operate remotely from other Emergency Operations Centres (EOCs) and from out in the field where the lahar was occurring.

The plans outlined the actions to be undertaken before (relating to readiness for the event, and reducing the risk), during (response phase) and after (recovery phase) the lahar took place, and the organisations responsible for those actions. As part of the readiness and reduction phase, warning levels numbered from 1 to 5 were assigned for different levels of the Crater Lake (Table 2). These warning levels were based on historic records of 
Table 1 Main organisations involved in the Northern and Southern Ruapehu Lahar Planning Groups

\begin{tabular}{|c|c|c|c|}
\hline Organisations & $\begin{array}{l}\text { Northern } \\
\text { plan }\end{array}$ & $\begin{array}{l}\text { Southern } \\
\text { plan }\end{array}$ & Responsibilities \\
\hline NZ Army & $\mathrm{X}$ & $\mathrm{X}$ & - Provide staff and resources as required \\
\hline Department of Conservation (DOC) & $X$ & $X$ & $\begin{array}{l}\text { - Respond to pager activation and notify } \\
\text { DOC staff } \\
\text { - Implement Tongariro National Park Lahar } \\
\text { response plan } \\
\text { - Provide advice on lahar status and } \\
\text { on-going support to emergency operations } \\
\text { centre (EOC)/Incident control point (ICP) } \\
\text { - Provide specialist personnel } \\
\text { - Follow own contingency plans }\end{array}$ \\
\hline $\begin{array}{l}\text { Environment Waikato (Regional } \\
\text { Council) }\end{array}$ & $X$ & & $\begin{array}{l}\text { - Activate group EOC } \\
\text { - Notify incident controller } \\
\text { - Provide regional liaison officer to ICP } \\
\text { - Monitor situation } \\
\text { - Coordinate regional response as required }\end{array}$ \\
\hline New Zealand Fire Service & $X$ & $\mathrm{X}$ & $\begin{array}{l}\text { - Provide staff as required to ICP and } \\
\text { roadblocks } \\
\text { - Provide staff to assist with evacuations }\end{array}$ \\
\hline Genesis Energy (Power company) & $\mathrm{X}$ & $\mathrm{X}$ & $\begin{array}{l}\text { - Follow own contingency plans } \\
\text { - Provide engineering advice to ICP }\end{array}$ \\
\hline $\begin{array}{l}\text { Good Health Wanganui (Wanganui } \\
\text { District Health Board (DHB)) }\end{array}$ & & $X$ & $\begin{array}{l}\text { - Establish liaison with St John ambulance } \\
\text { - Implement plans } \\
\text { - Alert other District Health Boards } \\
\text { - Health advisor for EOC provided } \\
\text { - Health media liaison and spokesperson } \\
\text { - Casualty documentation process estimated } \\
\text { - Coordination with police } \\
\text { - DHB and St John develop transport plan } \\
\text { - DHB coordinating health response }\end{array}$ \\
\hline $\begin{array}{l}\text { Horizons Manawatu-Wanganui } \\
\text { (Regional Council), Lakes DHB, } \\
\text { Waikato DHB, Bay of Plenty DHB }\end{array}$ & & $\mathrm{X}$ & $\begin{array}{l}\text { - Activate Group EOC } \\
\text { - Notify district councils, Incident } \\
\text { Controller, EOC staff, National Crisis } \\
\text { Management Centre (NCMC) } \\
\text { - Coordinate response across region } \\
\text { - Monitor situation and update NCMC } \\
\text { - Coordinate regional support } \\
\text { - SRLPG }\end{array}$ \\
\hline $\begin{array}{l}\text { GNS Science (GNS-Earth science } \\
\text { research agency) }\end{array}$ & & $X$ & $\begin{array}{l}\text { - Notify police communications of lahar } \\
\text { status } \\
\text { - Monitor lahar status } \\
\text { - Provide advice to EOC }\end{array}$ \\
\hline Justice Department & $\mathrm{X}$ & $\mathrm{X}$ & - Respond to pager \\
\hline $\begin{array}{l}\text { Ministry of Civil Defence \& } \\
\text { Emergency Management (MCDEM) }\end{array}$ & $X$ & $\mathrm{X}$ & $\begin{array}{l}\text { - Notify MCDEM staff } \\
\text { - Provide national liaison officer to ICP } \\
\text { - Monitor situation } \\
\text { - Coordinate national response to lahar as } \\
\text { required } \\
\text { - SRLPG }\end{array}$ \\
\hline Opus Consultants & $\mathrm{X}$ & $\mathrm{X}$ & - Contractors for infrastructure assessment \\
\hline
\end{tabular}


Table 1 (continued)

\begin{tabular}{|c|c|c|c|}
\hline Organisations & $\begin{array}{l}\text { Northern } \\
\text { plan }\end{array}$ & $\begin{array}{l}\text { Southern } \\
\text { plan }\end{array}$ & Responsibilities \\
\hline New Zealand Police & $\mathrm{X}$ & $\mathrm{X}$ & $\begin{array}{l}\text { - Staff road blocks } \\
\text { - Assist with evacuations } \\
\text { - Initiate Coordinated Incident Management } \\
\text { - System (CIMS) structure }{ }^{2} \\
\text { - Activate fire siren } \\
\text { - Provide staff to ICP/EOC } \\
\text { - Direct agencies as required } \\
\text { - Implement traffic management plan } \\
\text { - Check on state of bund } \\
\text { - Contact transit to open road } \\
\text { - Initiate CIMS structure } \\
\text { - Provide staff to check river } \\
\text { - Coordinate the use of aerial assistance in } \\
\text { upper mountain and river areas to make } \\
\text { public safe } \\
\text { - Coordinate Search and Rescue personnel } \\
\text { - SRLPG }\end{array}$ \\
\hline $\begin{array}{l}\text { Rangitikei and Wanganui District } \\
\text { Council }\end{array}$ & & $\mathrm{X}$ & $\begin{array}{l}\text { - Activate lahar response plan } \\
\text { - Advise local school } \\
\text { - Advise Chief Executive Officer and } \\
\text { Roading Manager } \\
\text { - Commence telephone tree call out } \\
\text { - Provide staff as required }\end{array}$ \\
\hline Ruapehu District Council (RDC) & $\mathrm{X}$ & $\mathrm{X}$ & $\begin{array}{l}\text { - Notify RDC staff } \\
\text { - Activate siren if not working } \\
\text { - Provide staff to EOC/ICP } \\
\text { - Initiate telephone tree calls } \\
\text { - Monitor RDC assets } \\
\text { - Advise recovery manager } \\
\text { - Maintain EOC } \\
\text { - Provide on-going info to EOC } \\
\text { - Bridge inspection } \\
\text { - Contact transit to open road } \\
\text { - SRLPG }\end{array}$ \\
\hline Search and Rescue (SAR) & $\mathrm{X}$ & $\mathrm{X}$ & - Activate if required \\
\hline Taupo District Council (TDC) & $\mathrm{X}$ & & $\begin{array}{l}\text { - Establish EOC } \\
\text { - Monitor TDC assets } \\
\text { - Resource to the EOC as required }\end{array}$ \\
\hline $\begin{array}{l}\text { Transpower (Owns and operates } \\
\text { New Zealand's electricity grid) }\end{array}$ & $\mathrm{X}$ & $\mathrm{X}$ & $\begin{array}{l}\text { - Implement agency lahar response plan } \\
\text { - Implement Transpower contingency plan } \\
\text { - Monitor situation } \\
\text { - Provide engineering advice to EOC }\end{array}$ \\
\hline $\begin{array}{l}\text { Transit New Zealand }{ }^{3} \text { (Responsible for } \\
\text { the New Zealand State Highway } \\
\text { network) }\end{array}$ & $\mathrm{X}$ & $\mathrm{X}$ & $\begin{array}{l}\text { - Notify staff and contractors } \\
\text { - Activate agency lahar response plan } \\
\text { - Deploy contractors to snow huts } \\
\text { - Activate/check variable message signs } \\
\text { - Contractors to close snow gates } \\
\text { - Provide engineering advice to ICP } \\
\text { - Provide contractors to road blocks } \\
\text { - Engineering inspection of Transit assets } \\
\text { - Implement traffic management plan }\end{array}$ \\
\hline
\end{tabular}


Table 1 (continued)

\begin{tabular}{|c|c|c|c|}
\hline Organisations & $\begin{array}{l}\text { Northern } \\
\text { plan }\end{array}$ & $\begin{array}{l}\text { Southern } \\
\text { plan }\end{array}$ & Responsibilities \\
\hline $\begin{array}{l}\text { Tranz Rail/Ontrack }{ }^{4} \text { (rail network } \\
\text { maintainer and operator) }\end{array}$ & $X$ & $X$ & $\begin{array}{l}\text { - Notify Police communications of activation } \\
\text { of Tranz Rail lahar warning system } \\
\text { - Cease train traffic } \\
\text { - Isolate power at Tangiwai rail bridge and } \\
\text { rail crossing } \\
\text { - Activate agency lahar response plan } \\
\text { - Provide advice to ICP as required } \\
\text { - All train traffic to remain stopped until } \\
\text { directed by Incident Controller }\end{array}$ \\
\hline $\begin{array}{l}\text { Winstone Pulp International (local } \\
\text { business in the lahar path) }\end{array}$ & & $\mathrm{X}$ & $\begin{array}{l}\text { - Implement lahar response plan } \\
\text { - Alert personnel and evacuate 'at risk sites' } \\
\text { - Advise ICP when evacuation complete }\end{array}$ \\
\hline Works Consultancy & & $X$ & - Contractors for infrastructure assessment \\
\hline \multicolumn{4}{|c|}{$\begin{array}{l}\text { Adapted from Galley et al. (2004), Northern Lahar Planning Group (2004), Southern Lahar Planning Group (2005) } \\
{ }^{1} S R L P G \text { agencies specifically named as part of the Southern Group in the group plan } \\
{ }^{2} \text { CIMS is a scalable command and control structure widely used in emergency management in New Zealand and in } \\
\text { many other countries under various incident management or coordination system names } \\
{ }^{3} \text { From } 2008 \text { Transit New Zealand has been operating as the New Zealand Transport Agency } \\
{ }^{4} \text { From } 1995 \text { the organisation responsible for maintaining New Zealand's rail network was named Tranz Rail. The name } \\
\text { was changed to Ontrack in } 2004 \text {. Since } 2008 \text { the rail network has operated under the new name of KiwiRail }\end{array}$} \\
\hline
\end{tabular}

previous lahars and the damage they caused (Galley et al. 2004). At Crater Lake Warning Level 1, when the lake was at a low level, trained staff were expected to be able to "initiate a response" within 30 min (Northern Lahar Planning Group 2004; Southern Lahar Planning Group 2005). In contrast, at Warning Level 4 , where the lake level was higher, trained staff were expected to initiate a response within $5 \mathrm{~min}$. As well as using the warning levels for the plan, public information was also provided around the current level of the lake and what this meant in terms of the likelihood and risk of a lahar occurring (e.g. leaflets, websites, free-phone) (Fig. 2).

For the response phase, the Plans outlined actions that each organisation should take for time periods following the activation of ERLAWS (that is, after 5, 30, 60, and $90 \mathrm{~min}$ from when a lahar warning had been triggered). For example, in the first 5 min following ERLAWS activation and pager receipt, common activities that agencies listed in the Plans had to do included responding to the pager, and contacting relevant internal and external personnel to notify them of the activation so they could start responding. Within $30 \mathrm{~min}$, Incident Control Points were required to be set up, the Coordinated Incident Management System (CIMS) structure initiated, road blocks established, lahar visually confirmed (if possible), key contacts and communication established (with any required information flowing), and individual agency contingency plans implemented. Sixty minutes after the lahar warning was received, much of the response was expected to be in 'monitoring and maintenance mode', where agencies were watching the progress of the lahar, staff were kept at key points as required (or deployed elsewhere if needed), and communication over the state of affairs was continuing. After 90 min the watching brief was expected to continue, and response was then to move toward the recovery phase.

After an official commencement of the recovery phase, the plans outlined the need for briefings, implementation of traffic management plans, provision of staff as required, engineering inspections of key infrastructure, and coordination of media and communication. These activities and monitoring of the situation continued for two hours, after which it was expected that debriefing and media activities would be occurring. 
Table 2 Crater Lake warning levels

\begin{tabular}{|c|c|c|c|c|c|}
\hline $\begin{array}{l}\text { Level of } \\
\text { readiness }\end{array}$ & $\begin{array}{l}\text { Lake } \\
\text { level } \\
(\mathrm{msl})\end{array}$ & $\%$ & Explanation & Actions & $\begin{array}{l}\text { Indicative time for lake to rise to } \\
\text { next alert Level in summer }\end{array}$ \\
\hline Normal & $\begin{array}{l}\text { Below } \\
2527\end{array}$ & $<95$ & $\begin{array}{l}\text { Base level of readiness as per normal civil } \\
\text { defence planning }\end{array}$ & $\begin{array}{l}\text { Planning, } \\
\text { preparation, } \\
\text { and training }\end{array}$ & \\
\hline Level 1 & 2526.5 & 95 & $\begin{array}{l}\text { Critical trigger point, } 3 \mathrm{~m} \text { below the new } \\
\text { rock overflow level. Waves caused by } \\
\text { eruptions and small landslides could } \\
\text { overtop barrier but the probability of a } \\
\text { small collapse lahar caused by a resulting } \\
\text { barrier failure is extremely low }\end{array}$ & $\begin{array}{l}\text { Planning } \\
\text { completed. } \\
\text { Full response } \\
\text { capability } \\
\text { available and } \\
\text { ready. } \\
\text { Response } \\
\text { within } 30 \mathrm{~min}\end{array}$ & \\
\hline Level $1 b$ & 2529.5 & 100 & $\begin{array}{l}\text { Lake full to the buried rock rim outlet } \\
\text { level and the base of the tephra dam. } \\
\text { Probability of barrier failure at this level is } \\
\text { still very low }\end{array}$ & & $\begin{array}{l}1-6 \text { months to fill from Alert } \\
\text { Level } 1 b \text { to } 2\end{array}$ \\
\hline Level 2 & 2533 & 108 & $\begin{array}{l}\text { Sudden collapse could produce a lahar } \\
\text { equivalent to the } 1975 \text { event. This is the } \\
\text { largest historic lahar that has passed } \\
\text { under the Tangiwai bridges (without } \\
\text { causing damage) and down the Tongariro } \\
\text { River } \\
\text { Conditional probability of barrier failure } \\
\text { at this level is } 1-2 \%\end{array}$ & $\begin{array}{l}\text { Response } \\
\text { within } 20 \mathrm{~min}\end{array}$ & $\begin{array}{l}\text { 0.7-1.9 months to fill from } \\
\text { Level } 2 \text { to } 3 \text {, or } 7.8 \text { months to } \\
\text { drop down to Level } 2 \text { from Level } \\
\text { 3, depending on infill rates. } \\
\text { This large variation is due to the } \\
\text { possibility of the filling spanning } \\
\text { fast and slow filling rates, and } \\
\text { seepage. Slow fill rates will } \\
\text { probably result in net drops in } \\
\text { lake level above about } 2532 \mathrm{~m}\end{array}$ \\
\hline Level 3 & 2535 & 113 & $\begin{array}{l}\text { Equivalent to a large moderately fast } \\
\text { lahar. Conditional probability of barrier } \\
\text { failure at this level is } 5-10 \%\end{array}$ & $\begin{array}{l}\text { Response } \\
\text { within } 10 \mathrm{~min}\end{array}$ & $\begin{array}{l}0.4-0.6 \text { months to fill from level } \\
3 \text { to } 3 b \text {, or } 3.2 \text { months to drop } \\
\text { down to level } 3 \text { from } 3 b\end{array}$ \\
\hline Level $3 b$ & 2536 & 115 & Conditional probability is $50-60 \%$ & & $\begin{array}{l}0.2-0.3 \text { months to fill from level } \\
3 b \text { to } 4 \text {, or } 1.1 \text { months to drop } \\
\text { down to level } 3 b \text { from } 4\end{array}$ \\
\hline Level 4 & 2536.5 & 116 & $\begin{array}{l}\text { Equivalent to a large, fast lahar. } \\
\text { Conditional probability is } 90 \%\end{array}$ & $\begin{array}{l}\text { Response } \\
\text { within } 5 \text { min }\end{array}$ & $\begin{array}{l}0.2-0.3 \text { months to fill from level } \\
4 \text { to } 5 \text {, or } 0.7 \text { months to drop } \\
\text { down to level } 4 \text { from level } 5\end{array}$ \\
\hline Level 5 & 2536.9 & 117 & $\begin{array}{l}\text { Lake at top of the tephra dam. Conditional } \\
\text { probability is } 100 \%\end{array}$ & & \\
\hline
\end{tabular}

Warning levels were associated with actions in the Northern and Southern Emergency Management Plans. Warning levels were also used to communicate to the public about the height of the lake in relation to the tephra dam and crater rim, and the rate at which the lake was filling with water (from Galley et al. 2004; Massey et al. 2009)

The Plans also included procedures for false alarms generated by ERLAWS. Only the Incident Controller could declare a false alarm based on either expert advice from the Duty Scientist monitoring the lahar, visual confirmation that there was no lahar, or if the time estimated for the lahar to reach Tangiwai had passed (Northern Lahar Planning Group 2004; Southern Lahar
Planning Group 2005). False alarms provided the opportunity to practice for an effective response.

Individual agencies also developed their own emergency management plans (e.g. the Central District Police Lahar Response Plan), which were consistent with both the Northern and Southern Plans. 


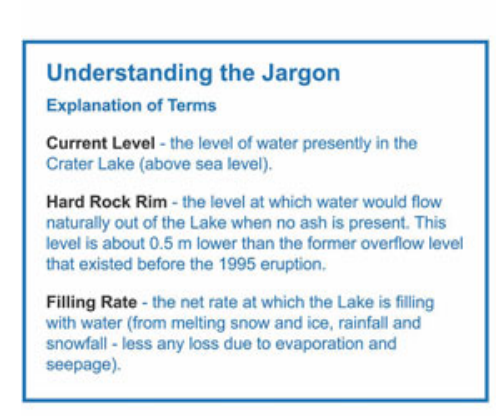

Fig. 2 Public information about the current level of the lake (e.g. for May 2004) and what this meant in terms of the likelihood and risk of a lahar occurring (replicated

A key part of planning for the lahar included practicing the response using the Plans. A training and exercise schedule was devised and included in the Plans. Some practice was also obtained when ERLAWS was activated accidentally (e.g. by bad weather) or when the EDS detected a small volcanic eruption was in progress in 2006 (Mordret et al. 2010). In this instance, responders received a message on their pagers saying that a "LAHAR [was] POSSIBLE", and they then knew they needed to start the process of stepping up to respond to a potential event.

\subsection{Communication}

Communication related to the lahar event needed to be considered in three distinct contexts. First, internal communication needed to occur between those involved in planning for and responding to the lahar. Inter- and intra-agency communication about the lahar issue developed over a period of 10 years from the occurrence of the 1995-1996 Ruapehu eruptions through to the 2007 lahar. At first, communication was constrained by issues including awareness of the historic Tangiwai disaster; the range and desirability of options available to treat the lahar risk, and differences in opinion over how that risk should be managed (DOC 1999; Keys 2009); a strong desire from
Crater Lake Status as at 2 May 2004

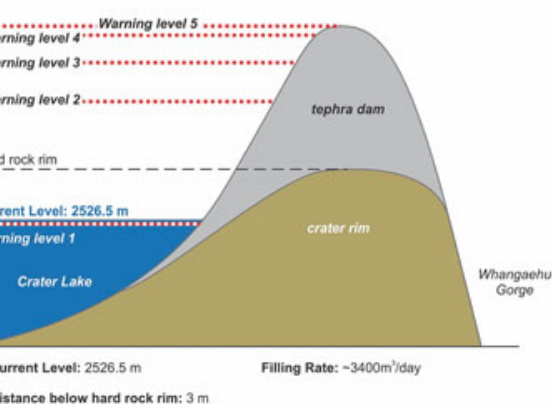

from a leaflet provided by the Wanganui-Rangitikei Emergency Management Committee 2004)

local iwi to let the lahar occur as a natural process; politics over who should be planning for and responding to the risk (Dittmer 2008; Keys 2009); and the quality of initial emergency plans created by RDC for responding to the lahar (Dittmer 2008). Such conflicts raised issues for effective communication around planning. Agencies often disagreed about the best approach to take, and who should be taking it.

The Minister of Conservation made a final decision about management of the lahar in 2001, guided by the Assessment of Environmental Effects report which outlined various treatment options (DOC 1999) and the debate which had occurred around the issue. The Minister's decision included the establishment of a physical warning system and building of a bund, combined with emergency planning (Dempsey 2002). Once the decision was made, a clear path was defined for the context in which future communication would take place. From this point onwards, inter and intra-agency communication developed as emergency management planning for the lahar evolved.

The second primary communication area was the external communication of public information about the status of the Crater Lake levels and response to the lahar event. A Lahar Information Management group, comprising the lead agencies in management of the event, was set up to address media communications related to the 
lahar (Southern Lahar Planning Group 2005). A lahar information plan, outlining management of information before, during and after the lahar, was included as part of the main Southern Emergency Management Plan appendices.

The third area of communication related to technical capacity. An effective response to the lahar relied on technical support, the primary one being timely communication about an impending lahar by ERLAWS. Other aspects of technical importance included the hardware required to report to others verbally and visually about the nature and progress of the lahar. It was imperative that these technical aspects were able to operate when the lahar occurred so that responders could communicate effectively.

The organisations involved in the planning process came from different geographic and functional jurisdictions (Leonard et al. 2005). Many agencies had not worked together in the past. This meant that diverse world views and expectations were likely to exist amongst responders, and there was a need to construct a shared mental model over response and communications (Paton et al. 1999). Galley et al. (2004) conducted an analysis of the planning process up to 2003 and made some observations on a variety of issues, many of which pertained to communication. They suggested that clarification of communication roles, lines of communication, and methods of communication should be undertaken to assist with creating a shared mental model. They recommended improving internal communication by continuing to conduct multi-organisation planning meetings, education, training and exercises. There was a need to ensure the technical ERLAWS system was robust and had adequate 'check-back systems'. Methods were also required for updating new information into plans and processes.

\section{The Lahar Event}

On Sunday 18 March 2007, after a prolonged period of wet weather, the tephra barrier began to breach (Massey et al. 2009). Around 10:06 on Sunday morning slumping started to occur at the
Crater Lake tephra dam. By 11:20 the dam was fully breached by rising lake levels due to heavy rainfall, and a lahar was flowing down the Whangaehu Valley. Although the volume of water was high, water was released in pulses over a $45 \mathrm{~min}$ period, and the event was considered 'moderate' in size (Wakelin 2007).

The ERLAWS sensor at site 1 on the dam (see Fig. 1) signalled a possible lahar just after 10:00 that morning. Between 10:06 and 11:42 all three ERLAWS sensors (Sites 1-3) and the Genesis sensor (Site 4) were triggered as the lahar travelled down the Valley. The alarms sent data to Tokananu Power Station and warning messages to police, rail and road authorities, and to infrastructure agencies. Alarms also initiated the closure of automatic barrier arms and flashing lights and signs on the State Highways (Keys 2007a).

By 11:00 am the Ohakune Incident Control Point (ICP) was activated, and responders had gathered at the ICP. Police had stopped rail traffic at Waiouru, farmers downstream were notified of the lahar, and signs and road blocks on State Highway 1 and State Highway 49 (SH49) were in place. At 11:28 the Whangaehu Valley telephone tree was activated, notifying valley residents of an impending lahar. By 11:35 the DOC lahar duty staff and response plan were activated and media releases were being prepared (Keys 2007a).

By around 11:44 the lahar had reached the bund built to prevent overflow from the lahar into the Tongariro River, but did not breach it. By 11:50 a helicopter had taken response staff to the area for visual confirmation of the lahar but bad weather and visibility kept observers from viewing the Crater Lake (Wakelin 2007).

From 11:50 to 15:30 other personnel who had not received the initial alerts were notified of the lahar including the Minister of Conservation, additional DoC staff, GNS research scientists, infrastructure providers and the media (Keys 2007a). During the day of the lahar event, over 100 media calls were taken by ICP staff. Lahar updates from the Emergency Operations Centre and the Ruapehu Area Manager fed information into media releases which were given to media as per the Emergency Management Plans' procedures (Wakelin 2007). 
The lahar reached Tangawai Rail Bridge and peaked at 13:30 and by 15:48 the warning lights on SH1 were turned off and the highway reopened. SH 49 was reopened at 16:06 and the Ohakune Incident Control Point was closed at 18:18 as the lahar passed down the lower Whangaehu River on its way to the sea (Keys 2007a). By the end of the day on 18 March the lahar and the emergency management response had run its course, with no major incidents occurring.

\section{Method for Communication Research}

As a Crater Lake tephra dam breach could be anticipated beforehand, it provided an excellent opportunity to study communication aspects of the planned emergency response prior to the lahar, and compare that with what happened in an actual event. Twenty interviews were undertaken between March and May 2006 with individuals from organisations involved in the response to the event. The interviews were semi-structured and contained questions about participants' organisations' plans for the wider response (including response to the ERLAWS warning system, roles and responsibilities, information management, communication, and training) and their expectations for responding to a lahar event. The interviews were repeated between April and June 2007, after the lahar had taken place. The same questions were asked, but this time participants were asked to reflect on how the actual response had gone compared with the anticipated response. All interviews were digitally taped and transcribed, and entered into the software package ATLAS.ti. Coding of the interviews was undertaken and key themes were extracted as described by Braun and Clarke (2006). The themes are organised under the following headings, which were identified as important in the discussion above:

1. Internal communication (in the planning and response process)

2. External communication

3. Technical capacity

\section{Results and Discussion: Communication for the Lahar Event}

The following section discusses the key themes related to communication that were identified during analysis of the data.

\subsection{Internal Communication}

\subsubsection{Internal Communication During the Planning Process}

Two types of internal communication were identified from the interviews. The first related to internal communication during the planning process. It included communication between agencies as the planning process took place, as well as communication within agencies. When the first set of interviews was undertaken in 2006, participants reported that communication during the planning process had been good. This is likely due to the 10-year timeframe it had taken for communication to develop. Tasks such as plan development, meetings, training, exercising and practices all contributed to better communication between agencies over time. These tasks contributed twofold: they helped build relationships between personnel; and they helped develop agreement over roles, responsibilities, and protocols for responding to the lahar, which could subsequently be embedded in a plan. An interviewee from Ontrack (responsible for the rail network) reflected on how communication had improved over time, based on the activities and training that people had undertaken together:

\footnotetext{
We've got better at communicating in the last three or four years. We use text messaging and conferencing a lot more and so we are actually going, shifting more to CIMS models now than the ad hoc system we used to work, because we all did CIMS training last year and so we therefore tend to work to a CIMS model.
}

On discussion about planning for future hazard events, an interviewee from the Police noted how relationships had been built and communication had improved, which would be useful for the future: 
I think what we would [use from the lahar planning] is communications with people like [GNS Science], DOC, Horizons, some of those relationships will last a long time ....and actually put us in good stead...in years to come.

People's expectations in 2006 of how communication would occur during a future lahar event seemed to predominantly correspond with the details in the plans that had been developed. Interviewees noted that communications, including roles and contact information, were "all laid out" in the plan (as quoted by one DOC interviewee). People's knowledge showed that those involved in the future response had a good understanding of how communication was likely to unfold, and their roles and responsibilities. Two people did anticipate that communication during an actual response may go wider than what the plan detailed, and suspected that some people may approach them personally to seek information.

Interviewees commented on the challenge of keeping momentum and interest in the planning process in the lead up to the lahar, due to the long time frame. As one interviewee from Genesis stated, “...it is just a challenge of keeping that [focus] going". They noted the need to keep information updated and circulated to internal staff and external responders so that people knew the status of the Crater Lake and any new readiness or response procedures that were put in place.

\subsubsection{Internal Communication During the Response}

The second type of internal communication related to anticipated and actual communication during the response. In general, according to all of the interviewees communication during the response worked well. People followed procedures that had been agreed upon, written down, and practiced. The relationships that had been developed were found to have largely assisted with response-related communication. People had noted prior to the lahar in 2006 that they sometimes had difficulty in getting hold of others during exercises, but that by following the protocols set down in the plans they were able to make contact with an alternate person.
There were a few instances where a breakdown in communication protocols occurred. In one instance, this was due to the relationships that had been developed during the planning process. Such a strong set of relationships were formed that one of the actions regarding confirmation of lahar activation in the planned response was undertaken out of sequence. A call was made by a key responder to another agency to confirm the lahar had occurred, but this person was not officially supposed to do it. Given the occurrence of this out-of-sequence action, the response was delayed slightly until the proper process was reinstated and the response moved forward as per the plan.

Additionally, some participants had expectations that they would receive calls from one of the primary responders to confirm the lahar activation (even though the plan had not outlined this as an action), but this was not the case. This created a period of anxiety and uncertainty as agencies waited for the official word to reach them that a lahar had indeed occurred.

Interviewees reported that multiple and diverse technical sources of communication during the response were useful, as both primary modes of communication, and as a back-up. Types of communication documented in both the Northern and Southern Emergency Management Plans included VHF radio, radio telephone (RT), landline and mobile telephones (for regular communications, telephone trees to notify local residents of the lahar, etc.), satellite phone, fax (e.g., for situation reports), email, conference calling, and web-cameras showing the river. Participants reported finding a common radio connection useful in aiding connections, as multiple people could sit in and listen on the channel for updates. For instance, in 2006 the Emergency Manager from Taupo District spoke about how they could "turn on our radios and do a listening brief because we can tune into DOC's radios, we can tune into the police radios and just see what's going on". A particular point was also made about the usefulness of having visual information through pictures and video footage of the lahar for understanding of how the event was progressing, and for having a common point 
of discussion between agencies that may not be sitting in the same room, but were able to see the same imagery. An emergency manager from Horizons Regional Council reflected on this point by saying:

\begin{abstract}
I think one of the biggest things, from a management point of view, was the webcam. That was a huge bonus. In fact, far more useful than I had ever expected it to be. I was talking on the phone to [...] the National Controller, and we were just chatting about how things were going and what information we were getting and all that sort of carry on and I said "We're projecting our webcam image up onto the wall" and he said "Yeah, we're doing the same." Which is good. That's what it was there for and we were making sure that the page was refreshing itself regularly and then [the National Controller] said, "Oh, refresh your page." So we refreshed the page and it had gone from the base of the tower to being over the top of the tower within a few minutes and immediately we knew what was going on, the guys in Wellington knew what was going on, we knew roughly how big it was, and from a management point of view that was really beneficial, being able to see it...
\end{abstract}

The Horizons participant also remarked that methods of communication such as radio, teleconferencing and web-cam were useful for understanding how the event was progressing in "real-time" and that the response needed to evolve to match its progress.

Videoconferencing between the different agencies was not undertaken for this event, but it was noted that for future events video-conferencing would be useful and might add an additional aspect to the response. As a Horizons emergency manager stated, "you look into a room and immediately get a feel for how things are going".

One of the 'surprises' faced by responders was that the amount of communication differed during the actual 2007 lahar event in comparison with the exercises and practices. An interviewee from the Police suggested that communications were of greater number during the event itself - "they tripled" - and that he was called by a variety of people both from official agencies (e.g., other Police, Ohakune ICP, Genesis), and unofficial sources (e.g., the public ringing to enquire about traffic disruption on SH1). The emergency manager from Wanganui District also said that his cell phone range constantly from agencies who rang him personally. The increase in communication also relates to the fact that relationships were so good between responders, that they would make contact with each other to find out more information, even if it wasn't specifically part of the plan. Conversely, one DOC interviewee located in the ICP said that she did "very little communication, because everyone had everything under control".

Frequent updates of information were praised by responders, who found the frequency useful for understanding what was going on, and responding. An interviewee from Ontrack gives one example of this:

The NCM [Network Control Manager] sent text messages out in a real timely manner right through the whole event. It was really good. You didn't actually have to ring the Network Control Manager up because the text messages were coming oh, round about every thirty to forty minutes [..] telling you what's going on.

\subsection{External Communication}

\subsubsection{Communication of Public Information Prior to the Lahar}

Prior to the lahar occurring information was provided to the public about the potential lahar and its management. Media interest was high, demonstrated by a number of stories on varying aspects of the lahar (Dittmer 2008). While there was a good effort made to provide timely, relevant and clear information about the potential lahar, sometimes confusion surrounded the information that was presented. The planning group attempted to be proactive in addressing confusion.

For example, some participants perceived that there was confusion amongst the public about the information provided on the warning levels for the lahar, and that more explanation was required. Additionally, as the warning levels changed (i.e. from 1 to 2) messages required updating and clarification. The Horizons 
emergency manager explained that in response to these communication needs, the 0800-freephone message was re-written to outline the current level of the lake, the likelihood and risk of the lahar occurring, and stated some actions that people should do. Messages for subsequent warning levels were prepared in advance in case they needed to change at short notice.

Interviewees also reported public confusion around some of the messages that were used on the lahar signs placed on SH1 to warn travellers about the potential for a lahar to occur. The Police noted that people did not understand the word 'lahar' that was used on the signs, so the terminology was changed to 'flash flooding' instead.

It was suggested by one of the interviewees that while the Lahar Information Group was active in both the readiness and the response phases, it could have directed more of its efforts to providing public information during the readiness phase. This would have allowed the provision of public information prior to the event, and efforts to provide information by various agencies (e.g., DOC, GNS Science, MCDEM, Horizons, etc.) could have been more integrated. It was suggested by one participant that a specific pre-lahar communication plan could have been developed to assist in readiness education.

\subsubsection{Communication of Public Information During Response to the Lahar}

Provision of public information about the lahar during the lahar response was generally effective, likely due to the pre-planning that had occurred to coordinate a media response. There was some discussion following the response that some of the media releases were a bit slow to be produced and disseminated to the public. This was thought to be because the person in charge of the media releases was unable to get to the ICP quickly, and another staff member was required to take over issuing media releases. A DOC interviewee suggested that the delay was related to the person who took over the media releases being "swamped" or overloaded with work and that it was a "staffing-level thing".

\subsection{Technical Capacity}

Prior to the Ruapehu lahar, interviewees predominantly reported that they had worked to develop a robust and integrated technical system of communication. ERLAWS needed to be reliable, and report as few false alarms as possible. For the most part this was the case, and it was estimated that there was one false activation per month (pers. comm. Keys 2007c). For the false alarms that did occur, protocols were put in place to identify the false alarm and shut down the response. These procedures were agreed on in the Plans, and practiced by the responders. If false alarms started to become too frequent, (e.g., in April 2006 there were four in one month) this was reviewed and new procedures put in place (pers. comm. Keys 2007c).

It was deemed essential that ERLAWS was linked into response systems of multiple organisations. It was also important that organisations were able to communicate together on compatible equipment. An Ontrack employee described how they ensured that the ERLAWS system was consistent with the other systems the Railways used to keep people safe. In another example, an interviewee from Genesis (2006) remarked: All DOC ERLAWS systems go through [...] the
Genesis handling systems because we have all the
communications that work on the mountain, so it
made sense to do that. So obviously, we work
really closely with DOC to make sure that their
ERLAWS systems which run through ours are
robust...

Technical communications worked well on the day of the lahar. ERLAWS was activated as expected, and everyone was able to communicate via the various technical means outlined in the planning and used in the exercises. There were only a couple of reports of responders having difficulty getting through to the ICP. These were 
mostly related to "black spots" in the operation of equipment (i.e. remote areas where equipment could not pick up signals), and the fact that the networks were busy. For example, a participant from Ontrack describes their communication difficulties with the ICP:

\footnotetext{
Initially, we had some problems trying to get through to the ICP centre at Ohakune. However, when we did get through they were really good. They gave us a cell phone number to get round the telephone numbers and I suggested to the Network Control Manager next time it happens, we've got a fax number for them, fax them instead of a fax saying 'please ring' and to make the contact, because it's important that we make that link.
}

This demonstrates how communication issues were solved by users being able to use different modes of communication to get around the problem, highlighting the importance of multiple modes of communication.

\section{Conclusions}

This chapter has provided a summary of the organisational communication that occurred before, during and after the 2007 Ruapehu Crater Lake break-out lahar. It is evident that effective communication before and during an event, can assist an effective response. The Ruapehu Crater Lake lahar had approximately 10 years of lead-in time before the event occurred. During this time, agencies were able to agree on an approach to manage the lahar risk, develop a technical warning system, implement mitigation measures, start a planning process, develop plans, hold exercises, and practice responding to false alarms. Being involved in many of these activities helped build a shared mental model of how a diverse collection of agencies were going to respond to the lahar (Galley et al. 2004; Paton et al. 1999). Exercises and practices also contributed to testing whether technical aspects of the warning system were robust, and allowing changes to be made to plans when necessary. The on-going communication and cooperation between agencies developed robust relationships that enabled people to work together in an effective manner. Given these conditions, the eventual response to the 2007 lahar was very effective, and communication reportedly worked well.

Only a few minor communication issues were reported.

- First, it was suggested that more effort could have been given to developing and integrating public information about the lahar prior to the event.

- Second, a number of participants in the study reported having trouble getting through to the ICP due to communications being very busy, but this problem was averted by responders making use of the diversity of communication modes and networks to find alternative paths to the ICP.

- Third, it was identified that communication levels during the lahar event itself were different from exercises or practices, and in some instances communication was seen to increase almost three-fold. This phenomenon should be highlighted for those planning for future events so that they have realistic expectations of what a response will be like.

- Finally, the development of relationships was extremely important in facilitating communication, planning, and an effective response. However, this produced some downfalls. Personal relationships affected the response, with at least one person bypassing communications actions in the plan in favour of communicating with someone else not noted in the plan, resulting in a brief communication breakdown. This minor issue should also be considered when undertaking planning for future events.

The findings from this research on the 2007 Ruapehu lahar support current literature on good practice for effective warnings. Leonard et al. (2008) suggest that there are 5 key components of an effective warning system including:

1. Early warning system hardware

2. Planning

3. Co-operation, discussions, and communication 
4. Education and participation

5. Exercises.

These five components are supported and informed by 'Research and science advice' and 'Effectiveness evaluation'. Although this chapter has focused on the key role of Co-operation, discussions and communication, it is evident that the actual response to the Ruapehu lahar contains most of the elements required for a warning to be effective. More development could perhaps have been undertaken in the areas of 'Education and participation' and 'Effectiveness evaluation, but other areas were robustly handled. This may explain why the response to the Ruapehu lahar was very effective.

The 2007 Ruapehu lahar was a unique event in that the nature of a potential future lahar could be reasonably well anticipated. The Crater Lake took over 10 years to fill to the point where the lahar occurred, which allowed a long lead in time to build relationships and plan for a response. Not every event will have the luxury of such a lead in time and therefore it is even more imperative that relationship-building, planning and communication takes place before events occur, to allow for an effective response. With respect to future events from Ruapehu and the nearby Central North Island volcanoes, the Central Plateau Volcanic Advisory Group has since been established for this purpose. Meeting two to three times per year, scientists, Civil Defence \& Emergency Management personnel, planners, communicators, emergency services and local community representatives discuss plans for the volcanoes of Ruapehu, Ngauruhoe and Tongariro, and build relationships. This structure is likely to have helped in the response to the eruptions of Tongariro in 2012.

Acknowledgements The authors wish to thank all of the participants who talked to us during the course of the research, and shared their experiences about planning for and responding to the 2007 Ruapehu Crater Lake lahar. We also acknowledge the support of the New Zealand Natural Hazards Platform, which provided funding for the research to take place.

\section{References}

Board of Inquiry (1954) Tangiwai railway disaster report. Digital reproduction by Transport Accident Investigation Commission (6 September 2001) based on the original publication. Wellington, New Zealand

Braun V, Clarke V (2006) Using thematic analysis in psychology. Qual Res Psychol 3(2):77-101

Cronin SJ, Hodgson KA, Neall VE, Palmer AS, Lecointre JA (1997) 1995 Ruapehu lahars in relation to the late Holocene lahars of Whangaehu River, New Zealand. NZ J Geol Geophys 40(4):507-520

Dempsey B (2002) Planning for a lahar event. Tephra 19:18-19

Department of Conservation (1999) Environmental and risk assessment for the mitigation of the hazards from Ruapehu Crater Lake. Assessment of Environmental Effects Report, Department of Conservation, Turangi

Dittmer M (2008) The Clockwork Lahar. Unpublished Masters thesis in Communication Management. Massey University, Palmerston North, New Zealand, $235 \mathrm{pp}$

Galley I, Leonard GS, Johnston DM, Balm R, Paton D (2004) The Ruapehu lahar emergency response plan development process: an analysis. Australasian J Disaster Trauma Stud 1

Hancox GT, Nairn IA, Otway PM, Webby G, Perrin ND, Keys JR (1997) Stability assessment of Mt. Ruapehu crater rim following 1995-1996 eruptions. Client Report 43605B Institute of Geological and Nuclear Sciences Limited

Hancox GT, Otway PM, Webby MG (1998) Possible effects of a lahar caused by future collapse of the tephra barrier formed at the Mt. Ruapehu Crater Lake outlet by the 1995-96 eruptions. Client Report 43711B. Institute of Geological and Nuclear Sciences Limited

Johnston DM, Bebbington MS, Lai C-D, Houghton BF, Paton D (1999) Volcanic hazard perceptions: comparative shifts in knowledge and risk. Disaster Prev Manag 8(2):118-126

Keys HJR (2007a) Lahar lahar! Tongariro J Annu 15:22-23

Keys HJR (2007b) Lahars of Ruapehu Volcano, New Zealand: risk mitigation. Ann Glaciol 45:155-162

Keys H (2007c) Discussion about ERLAWS (personal communication)

Keys HJR (2009) Lessons from the warning system and management for Ruapehu's Crater Lake breakout event of 18 March 2007. Paper presented at the symposium of NZ society on large dams, 18 August 2009, Wellington, New Zealand

Keys H, Green P (2002) The crater lake issue-a management dilemma. N Z Alp J 118-120

Keys HJR, Green PM (2008) Ruapehu lahar New Zealand 18 March 2007: lessons for hazard assessment and risk mitigation. J Disaster Res 3(4):284-296 
Leonard GS, Johnston DM, Paton D (2005) Developing effective lahar warning systems for Ruapehu. Plann Quart 158:6-9

Leonard GS, Johnston DM, Paton D, Christianson A, Becker JS, Keys H (2008) Developing effective warning systems: ongoing research at Ruapehu volcano, New Zealand. J Volcanol Geoth Res 172 (3/4):199-215. doi:10.1016/j.jvolgeores.2007.12.008

Massey CI, Manville V, Hancox GH, Keys HJ, Lawrence C, McSaveney MJ (2009) Out-burst flood (lahar) triggered by retrogressive landsliding, 18 March 2007 at Mt. Ruapehu, New Zealand-a successful early warning. Landslides 1-13

Manville V, Hodgson KA, Nairn IA (2007) A review of break-out floods from volcanogenic lakes in New Zealand. NZ J Geol Geophys 50:131-150

Mordret A, Jolly AD, Duputel Z, Fournier N (2010) Monitoring of phreatic eruptions using interferometry on retrieved cross-correlation function from ambient seismic noise: results from Mt. Ruapehu, New Zealand. J Volcanol Geoth Res 191(1):46-59
Northern Lahar Planning Group (2004) Ruapehu Lahar: emergency management plan (Northern). Taupo District Council, Taupo, p 49

Norton J (2002) Evaluating the risks and coordinating planning. Tephra 19:20-21

Paton D, Johnston D, Houghton B, Flin R, Ronan K, Scott B (1999) Managing natural hazard consequences: planning for information management and decision making. J Am Soc Prof Emerg Plann VI:37-48

Southern Lahar Planning Group (2005) Ruapehu lahar: emergency management plan (Southern). Ruapehu District Council, Ruapehu

Taig T (2002) Ruapehu lahar residual risk assessment. TTAC Limited, UK. TTAC Limited Report N19. 83 p

Wakelin D (2006) An illustrated guide to Lahars. Tongariro J Ann 14:44-49

Wakelin D (2007) Lahar lahar! Tongariro J Ann 15:17-21

Wanganui Rangitikei Emergency Management Committee (2004) Crater Lake status as at 2 May 2004, Lahar Newsletter for Whangaehu Valley Residents, May 2004, p 4
Open Access This chapter is licensed under the terms of the Creative Commons Attribution 4.0 International License (http://creativecommons.org/licenses/by/4.0/), which permits use, sharing, adaptation, distribution and reproduction in any medium or format, as long as you give appropriate credit to the original author(s) and the source, provide a link to the Creative Commons license and indicate if changes were made.
The images or other third party material in this chapter are included in the chapter's Creative Commons license, unless indicated otherwise in a credit line to the material. If material is not included in the chapter's Creative Commons license and your intended use is not permitted by statutory regulation or exceeds the permitted use, you will need to obtain permission directly from the copyright holder. 